\title{
APOSTLES BEFORE PAUL AND DURING PAUL'S TIMES
}

The concept of apostle before Paul and during his times was broad enough to embrace three groups of people - the Jerusalem appearance apostles, wandering Hellenistic missionaries commissioned by the Holy Spirit and representatives of congregation. Influenced by the Jewish legal institution of "messenger", Jesus sent out his disciples for a temporary and nationally limited pre-resurrection mission. Twenty years or so after the resurrection, the existence of two missionary concepts of apostle (the Jerusalem appearance apostles, wandering missionaries) reflects the two communities in the primitive Church (Palestinian Jewish Christianity, Hellenistic Jewish Christianity) that implemented Jesus' pre-resurrection concept. Paul, starting as a wandering missionary apostle, grounded his apostolate in the Christ event and thus marked the trajectory of apostle concept development that ultimately ended as a restrictive category for the Twelve only.

\section{Introduction}

It is without a question that there were apostles before Paul in the primitive Christianity (cca $30 \mathrm{CE}-64 \mathrm{CE}$ ) and that Paul was not the only apostle in his times. The aim of this article is to describe all the possible concepts of an apostle before and during Paul's time and provide possible explanation of their origin and relationship. Naturally, our primary witness will be Paul's genuine letters (1 Thess; 1, 2 Cor; Gal; Phil; Philem; Rom), although older strata of tradition relevant to our topic in other New Testament writing will be also taken into consideration.

To relate Paul's self-understanding as an apostle to those who are also named apostles is not an easy task. First of all, one has to take into consideration that Paul as an apostle was of an extraordinary kind. [1] Paul was aware of all the difficulties his prior life carried as a Pharisee (Phil 3:5) who persecuted the church (Gal $1: 13$ ) would cause to his apostolic work. Moreover, his special preoccupation with the Gentiles was often a thorn in flesh of Jewish Christianity.

There is also another difficulty if one seeks to ponder Paul's understanding of those he named "the other apostles." Except for fervent words towards false apostles (2 Cor 11:13) or super apostles ( 2 Cor 11:5; 12:11f) whose identity is much debated and far from certain, there are only scattered notes about those whom he regarded as regular apostles. However, there are several verses where Paul addresses them. In the following lines we will seek to establish with all possible certainty what Paul meant when he applied the word apostle to other accredited messengers of Jesus.

\section{Meaning of the word avpo, stoloj - an apostle as a witness of the Risen Lord}

In Gal 1:17, Paul writes that after his call on the Damascus road, he did not go to Jerusalem to consult the gospel with the apostles before him ( $\mathrm{Gal}$ 1:16f). From this statement we can conclude that at the time of Paul's call, there was a closed circle of apostles in Jerusalem. Although it would be natural to identify them with the Twelve, this verse by itself does not give us this credential. Three years after his call, he goes to Jerusalem for the first time. He visited Cephas and he did not see any other apostle except James, the brother of the Lord (Gal 1:19).

More light on this group of apostles is shed by the well known tradition formula in 1 Cor 15:3ff. In these verses Paul, relying on a tradition handed to him (paradi, dwmi), reminds the Corinthians about the gospel he has preached to them. The chronological list of those to whom the Christ appears runs as follows:

"...he appeared to Cephas, then to the twelve. Then he appeared to more than five hundred brothers ...... Then he appeared to James and then to all the apostles. Last of all, as the one ultimately born, he appeared also to me. (NRSV)"

Although it is difficult to demarcate what is the tradition that Paul received and what part is his contribution, the text reveals an important feature of apostles. As the text reads, the risen Lord appeared to all the apostles (1 Cor 15:7). Hence, the constitutive mark of an apostle is a witness to a Christophany. During the limited time of the Christ's post resurrection appearances, he appeared to all the apostles. The best way to understand this appearance is to

\footnotetext{
* Adrian Kacian

Department of Pedagogy, Psychology and Social Science, Faculty of Science, University of Zilina, E-mail: adrian.kacian@fpv.utc.sk
} 
picture it as a single event that happened in Jerusalem. Although Paul at that time was a persecutor of the church and was not present at this particular appearance, he was granted a special appearance which all the appearances ended with. Although "all the apostles" does not include him, he understood his special appearance as the essentially equal with the appearance to all the apostles. The apparent tension that he was not with the all apostles, but that he was granted the same constitutive Christophany, corresponds to his life long battle for his apostleship, because of its special "ultimately born" (1 Cor 15:8) character.

This text reveals another set of information. Although the appearance of the risen Lord was essential, it was not unique and limited exclusively only to apostles. In 1 Cor 15:6 we read that the Lord appeared to more than five hundred brothers who were not considered to be apostles. This fact forces us to ponder more on the character of the Christophany. We can turn to Paul himself to see that he understood it as a much more than an event than a mere static appearance or as a simple assurance of the resurrection. In Gal 1:15f, according to the fashion of the Old Testament prophets, the appearance is expressed in terms of a commission to preach the gospel to the Gentiles. The same understanding is found in the appearance stories in the gospels (Mt 28:16-20; Jn $20: 19-23 ; 21: 15-18)$. Although they belong to the later layers of tradition, the Christophany in them cannot be separated from commission and sending to preach the gospel. In conclusion we can state that the appearances to the apostles were essentially bind to and expressed as a commission to preach the gospel.

The necessity of the witness of risen Lord is confirmed by Paul statement in 1 Cor 9:1ff. In this passage Paul gives the Corinthians an example that he was able to refrain from his apostolic rights to be supported by them in order not to "put an obstacle in the way of the gospel of Christ" (1Cor 9:12). In 1Cor 9:5 he lists "other apostles and the brothers of the Lord and Cephas" (oi' loipoi. avpo, stoloi kai. oi' avdelfoi. tou/ kuri, ou kai. Khfa/j) as those who also have the right to live on the expanses of a congregation. Even if it is possible to view the "other apostles" as wandering missionaries commissioned by the Holy Spirit, the connection with the reference to seeing the Lord in 1Cor 9:1 links this group to the Christophany group.

To summarize, we can say that in the above mentioned texts we meet apostles before Paul as a confined group of witnesses to the risen Lord, who were commissioned through this appearance directly by him to preach the gospel. Their activity took place predominately in Jerusalem and the vicinity, although 1 Cor 9:5 suggests missionary travel with wider range.

\section{Meaning of the word avpo, stoloj - an apostle as a wandering missionary empowered by the Holy Spirit}

We meet this slightly different concept of an apostle in Act 13:1-3. In Antioch, during the worship, on the order of the Holy Spirit, Paul and Barnabas are set apart (avfori, zw) and called (proskale,w) to missionary work. After fasting and praying, the representatives of the Antioch congregation (prophets and teachers) lay hands on Paul and Barnabas and send them off on the so called first missionary journey. Although they are not called explicitly apostles in this particular passage, this title is applied to them when they are on their way in Acts 14:4, 14 (The fact, that Paul and Barnabas are named expressis verbis apostles regardless the limitation of this term to the Twelve in Luke's writings, points to the direction that Luke used a traditional material reflecting the situation in early apostolic times). The differences from the previous concepts are as follows: In the previous concepts, the commission was done by the risen Lord during his post-resurrection appearances, limited in number and without human agency involved. Here it is the Holy Spirit who orders the representatives of the Antioch congregation to choose Paul and Barnabas. After spiritual preparation of fasting and prayers, they are publicly sent for mission via human agency - laying of the hands.

From all the information we have, it looks like that Paul's opponents in 2 Corinthians belonged to this class. Although they presented themselves as "apostles of Christ" (avposto, 1oij Cristou/, 2 Cor 11:13), Paul tagged them with a different names. For him they were "false apostles" (yeudapo, stoloi, 2 Cor 11:13) or "super apostles" (u 'perli, an avpo, stoloi, 2 Cor 11:5; 12:11). They stressed their ecstatic pneumatic visions (2 Cor 12:2), spirit led powerful speeches (2 Cor 10:10; 11:6) and mighty deeds wonders and miracles as signs of an apostle (2 Cor 12:12). All this evidence points to the fact that their mission was grounded in a pneumatic vocation. On the other hand, they sought to balance this pneumatic vocation with reference to their Jewish pedigree (2 Cor 11:12) and legitimize it with letters of recommendation from other congregations (2 Cor 3:1).

There is a possibility to understand wandering charismatic missionaries behind apostles in Rev 2:2. In the letter to the church in Ephesus, they are mentioned as evildoers and false apostles. However, the data is not sufficient to yield a clear result. This concept of an apostle is also found in Did 11: 3-7 that reads:

"Let every apostle, that come to you be received as the Lord. But he shall not remain except one day; but there be need, also the next; but if he remains three days, he is a false prophet. And when the apostle goes away, let him take nothing but bread until he lodges; but if he asks money, he is a false prophet."

It is worthy to note, that this text treats apostle and prophet as synonyms. This fact only stresses the role of the Holy Spirit in this apostle concept.

To summarize, the core of this concept of an apostle is commission or empowerment by the Holy Sprit through the agency of fellow Christians or a congregation. These apostles are wandering missionaries who are not supposed to possess any extra material belongings except the necessary food to sustain their lives until the next stop. They preach the gospel as the exponents of the previous group. However, there is one essential difference. The members of the previous group had seen the risen Lord. This christophany, that occurred during the limited time between the Christ's resur- 
rection and ascension, was a constitutive of their future occupation as apostles. This very fact is missing in the portfolio of these wandering missionaries.

\section{Meaning of the word avpo, stoloj - an apostle as a representative of church [2]}

We find two instances, where the word is used of representatives of churches. In 2 Cor 8:23 he speaks of two brothers, who are "avpo, stoloi evkklhsiw/n" and who join Paul and Titus in their missionary affairs. In Phil 2:25 the word describes Epaphroditus, who is Paul's "brother and co-worker and fellow soldier, your (the church in Philippi) messenger (avpo, stoloj) and minister to my need." As is evident from the citation, Epaphroditus is commissioned by the Christian congregation in Philippi. Paul uses the verb avposte, $11 \mathrm{w}$ in the same fashion in 2 Cor 12:17f. He speaks about sending Titus plus one more brother to the Corinthians to administer the collection. In all these instances, Paul speaks of Christians who are commissioned by human authorities (either a congregation or a single person) to perform a specific task. The commission in all probability is temporally limited, and after finishing the task, they return to their regular occupation. It would be wrong to conceive of them as a secondary rank Christians performing exclusively corroborative tasks of administration void of any preaching and witness. In 2 Cor 8:18 we read about one of the two brothers who joined Paul and Titus; he was famous among all the churches for his service ( ${ }^{\prime}{ }^{\prime} e$; painoj evn tw/ | euvaggeli,w| "preaching" NRSV) to the gospel. Although as Christians, they could not be thought of without an encounter with the risen Christ; nevertheless, they were not directly commissioned by him to preach the gospel. They were sent by a congregation or by another individual. Also we lack references to a missionary activity - to preach gospel to those "who have never heard of him" (Rom 15:20f). These are precisely the two features (direct commission by the risen Christ and missionary activity), that differentiate the apostle Paul from these church representatives.

\section{Conclusion}

As can be seen from the previous sections, there is nothing like a unified concept of an apostle during the time of Paul. As was shown, in the relevant texts, we meet three different expressions of an apostle. All of the exponents are "send ones" in a general sense, but they differ by the sending agent and also by the task. The first group is clearly linked with Jerusalem and post resurrection appearances of Jesus. These apostles are commissioned by the Risen Lord to preach the gospel. This group includes Peter, the Twelve, James [3] and individuals whose task was predominately to preach the gospel to the Jews. On the other hand, Paul for sure and probably Barnabas [1, 4-6] also belonged to this group although they were in service to the Gentiles. In addition to these names, we can state with high probability that Andronicus and Junia (Rom 15:7) also belonged to this group of appearance apostles, although that is the all that can be said about them. [7] Even if this group was limited in numbers, it was definitely larger than Peter, the Twelve and Paul, as was traditionally held.

The second expression of the word apostle lacks the appearance of the risen Lord. This concept presents wandering missionaries to the Gentile churches who are commissioned by the Holy Spirit. In the New Testament, this concept is linked with Antioch as the basis for the Gentile mission. This two so called technical concepts of an apostle, who were send to preach the gospel, are joined by a non technical concept (their primary task was not to preach the gospel) of messenger of churches - third usage of the word apostle in the early Christianity.

Even if the previous picture gives three different concepts of an apostle, we have to keep in mind, that the border lines between them were not precisely drawn and defined. Although we cannot agree with Barrett, who suggests only two clear concepts on the extremes of the scale (envoys of the churches on one hand and apostle of Jesus Christ on the other hand) without a clear possibility to identify a position somewhere in between, [8] we have to be aware that a categorization belonged to the later period. Before Paul and during his time, the concept of an apostle seems to be very fluid.

It is beyond doubt that the New Testament apostle concept was born on Jewish soil. The Jewish convention of $\mathrm{xl} ; \mathrm{V}^{\prime}$ or $\mathrm{x}$; yliv' "messenger" covers the sending of a variety of figures ranging from the Old Testament prophets up to Temple tax collectors of later rabbinic period. This provides the formal framework for the concept of an apostle in the primitive Christianity. This formal congruency consists of mainly two features: a commission that is bound together with an authorization and a personal representation of the one who sends. On the other hand, it has to be kept in mind that the legal concept governing the rabbinic apostle was not carried over into the agenda of the primitive Christian apostle. Also content wise we meet a unique phenomenon in New Testament apostleship: the gospel proclamation of the crucified and risen Christ that inevitably leads to step outside of the ethnic boundaries and engage in mission - a factor lacking in the agenda of the rabbinic apostles or the Old Testament prophets.

When this Jewish soil received a seed of witness of the Risen Lord and the power of the Holy Spirit operating in the midst of the first converts, the term avpo, stoloj was coined as a clear expression of a function - to go and proclaim the good news. Twenty years or so later we meet three various uses of the term: it is applied to wandering missionaries empowered by the Holy Spirit, the Jerusalem witness apostles, and the emissaries of churches. Existence of the third group indirectly demonstrates the influence of the $\mathrm{xl} ; \mathrm{V}^{\prime}$ concept on the first Christians. Regarding the first two, it is impossible to provide a coherent theory of their relationship and dependence due to the scarcity of our sources. However, the picture of two parallel and equivalent missions, one to the Jews and one to Gentiles, as evidenced in Gal 2, points to the direction of two communities of the primitive Church that were related and to some degree also autonomous: Palestinian 
Jewish Christianity on one side and Hellenistic Jewish Christianity on the other. One was the cradle for the Jerusalem witness apostles, the other for the wandering missionary apostles.[9]

The apostle Paul shares in both camps. He was probably regarded mainly by the others as a representative of a wandering missionary camp, and that might have been a starting point of his carrier. However, his retrospect theological reflection on his Damascus road experience brought him to the conclusion that his experience was essentially identical with the post resurrection Christophanies. And this understanding brought him clearly to the other camp. This grounding of his apostolate in the Christ event has to be understood in the context of his battle against opposition tendencies who sought to anchor the primitive apostolate in either pneumatic-charismatic experience or institutional authority. This emphasis proved to be influential for the future trajectory of an apostle concept. In Lukan writings, we find an ultimate con- clusion of this emphasis: the essential feature of an apostle is the Christ event in its totality, including not only the witness of the Risen Lord but also a witness to the earthly career of Jesus of Nazareth. When this concept won the day around 80 CE, Paul was no longer alive. Although this definition formally excludes him from the apostolic band, this fact does not jeopardize his position in the church after his death as the apostle par excellence. On the other hand it shows that at that stage of the Church life, the Jesus tradition became an important correlative of the presence and power of the risen Lord in the Holy Spirit in the Church. Therefore when the Christian church left the apostolic age, two out of three previous concepts of an apostle (a wondering missionary empowered by the Holy Spirit; and a representative of church) disappeared and the word apostle was reserved exclusively for those who were witness of the Risen Lord and Jesus of Nazareth, namely the Twelve.

\section{References}

[1] RENGSTORF, K. H.: TDNT, 1974, pp. 1:407.

[2] BARNETT, P. W.: DPHL, 1993, pp. 45.

[3] FEE, G. D.: The First Epistle to the Corinthians, Eerdmans, Grand Rapids, 1987.

[4] BROWN, R. E.: NJBC, pp. 1377.

[5] LIGHTFOOT, J. B.: The Epistle of St. Paul to the Galatians, 10 ed., Zondervan, Grand Rapids, (1865) 1957.

[6] SCHMITHALS, W.: The Office of Apostle in the Early Church, Abingdon Press, Nashville, 1969.

[7] ROLOFF, J.: Theologische Realenzyklopädie, 3 ed, Vol. 3, 3 ed. (Eds.: H. R. Balz, G. Krause, G. Müller), Walter de Gruyter, Berlin, 1978, pp. 3:430.

[8] BARRETT, C. K.: The Signs of an Apostle, Fortress Press, Philadelphia, 1972.

[9] BERGE, P. S.: Word \& World 1992, 1, 127. 